\title{
Phylogenetic and functional marker genes to study ammonia-oxidizing microorganisms (AOM) in the environment
}

\author{
Pilar Junier • Verónica Molina • Cristina Dorador • \\ Ora Hadas • Ok-Sun Kim • Thomas Junier • \\ Karl-Paul Witzel • Johannes F. Imhoff
}

Received: 10 June 2009/Revised: 28 August 2009/Accepted: 28 August 2009/Published online: 24 September 2009

(C) The Author(s) 2009. This article is published with open access at Springerlink.com

\begin{abstract}
The oxidation of ammonia plays a significant role in the transformation of fixed nitrogen in the global nitrogen cycle. Autotrophic ammonia oxidation is known in three groups of microorganisms. Aerobic ammonia-oxidizing bacteria and archaea convert ammonia into nitrite during nitrification. Anaerobic ammonia-oxidizing bacteria (anammox) oxidize ammonia using nitrite as electron acceptor and producing atmospheric dinitrogen. The isolation and cultivation of all three groups in the laboratory are quite problematic due to their slow growth rates, poor growth yields, unpredict-
\end{abstract}

P. Junier

Laboratory of Microbial Ecology, University of Neuchatel,

2009 Neuchatel, Switzerland

\section{P. Junier $(\bowtie)$}

Environmental Microbiology Laboratory,

École Polytechnique Fédérale de Lausanne,

CE 1644 (Centre Est), Station 6,

1015 Lausanne, Switzerland

e-mail: Pilar.Junier@epfl.ch

\section{Molina}

Departamento de Oceanografía \& Centro de Investigación

Oceanográfica en el Pacífico Sudoriental,

Universidad de Concepción,

Casilla 160-C,

Concepción, Chile

C. Dorador

Departamento de Acuicultura, Facultad de Recursos del Mar,

Universidad de Antofagasta,

Antofagasta, Chile

O. Hadas

Israel Oceanographic and Limnological Research,

The Yigal Allon Kinneret Limnological Laboratory,

P.O. Box 447, Migdal 14950, Israel able lag phases, and sensitivity to certain organic compounds. Culture-independent approaches have contributed importantly to our understanding of the diversity and distribution of these microorganisms in the environment. In this review, we present an overview of approaches that have been used for the molecular study of ammonia oxidizers and discuss their application in different environments.

Keywords AOB · AOA · Anammox · Functional marker . Phylogenetic marker

\section{O.-S. Kim}

School of Biological Sciences and Institute of Microbiology,

Seoul National University,

56-1 Shillim-dong, Kwanak-gu,

Seoul 151-742, Republic of Korea

T. Junier

Computational Evolutionary Genomics Group,

University of Geneva,

1211 Geneva, Switzerland

K.-P. Witzel

Max-Planck-Institute for Evolutionary Biology,

24306 Plön, Germany

\author{
J. F. Imhoff \\ Leibniz-Institute of Marine Sciences IFM-GEOMAR, \\ Duesternbrooker Weg 20, \\ 24105 Kiel, Germany
}




\section{Introduction}

Ammonia oxidation is generally regarded as the ratelimiting step on autotrophic nitrification in a wide range of environments (Kowalchuk and Stephen 2001). Until recently, autotrophic ammonia oxidation was thought to be restricted to two groups of aerobic bacteria called ammoniaoxidizing bacteria (AOB), responsible for the oxidation of ammonia to nitrite. In the past few years, a series of new discoveries have challenged this view. First, the existence of anaerobic ammonia oxidation (anammox), which had been hypothesized based on thermodynamic calculations (Broda 1977), was confirmed in a pilot denitrifying wastewater treatment plant (Mulder et al. 1995). Further studies demonstrated that the anammox process is carried out by bacteria (van de Graaf et al. 1995) that were identified as members of the Planctomycetes (Strous et al. 1999). Second, analysis of metagenomic libraries from seawater (Venter et al. 2004) and soil (Treusch et al. 2005) revealed the existence of putative genes involved in ammonia oxidation in genomic fragments derived from uncultivated Crenarchaeota. The confirmation of archaeal ammonia oxidation was obtained by the cultivation of an ammonia-oxidizing archaeon (AOA) named Candidatus Nitrosopumilus maritimus (Könneke et al. 2005). Recently, the cultivation of two other thermophilic AOA, Candidatus Nitrosocaldus yellowstonii (de la Torre et al. 2008) and Candidatus Nitrososphaera gargensis (Hatzenpichler et al. 2008), has been reported.

Ammonia oxidation is central to the global nitrogen cycle. Nitrate, the product of aerobic ammonia and nitrite oxidation, is a fixed inorganic nitrogen source available for primary production in aquatic environments (Capone and Carpenter 1982). However, in terrestrial ecosystems, leaching of nitrate (e.g., from fertilized soil), other $\mathrm{NO}_{\mathrm{x}}$ compounds (through incomplete denitrification by ammonia oxidizers; Conrad 1996) and $\mathrm{N}_{2}$ (only in the case of anammox; Kartal et al. 2007), can lead to a net loss of nitrogen. Anaerobic ammonia oxidation maybe an important sink for fixed inorganic nitrogen in aquatic environments (Thamdrup and Dalsgaard 2002; Dalsgaard et al. 2003; Kuypers et al. 2003, 2005), and it is used for the removal of nitrogen from wastewater in sewage treatment plants (Jetten et al. 2001; Schmidt et al. 2003). Additionally, the cometabolic activity of enzymes involved in ammonia oxidation (i.e., ammonia monooxygenase, AMO) may be used as a mechanism for initiating the removal of certain pollutants (e.g., chlorinated aliphatics, alkanes, alkenes, or aromatics) from soils, waters, and sediments (Arp et al. 2001).

Ammonia-oxidizing microorganisms (AOM) are a diverse microbial group (Fig. 1) found in most environments where ammonia is available: soils, freshwater, and marine habitats. AOM are slowly growing bacteria with low maximum growth yields in cultures. Without the use of multiple complimentary approaches, we would have a very restricted vision of their abundance, function, diversity, and distribution in nature. This review will focus on phylogenetic and functional molecular marker genes used so far to study AOM and in addition will discuss the application of these markers for ecological studies.

\section{The 16S rRNA gene}

The most traditionally used phylogenetic marker for studying microbial communities is the $16 \mathrm{~S}$ rRNA gene. AOB represent one of the bacterial groups for which the amplification and analysis of the 16S rRNA gene has been successfully used (Bothe et al. 2000; Kowalchuk and Stephen 2001; Juretschko et al. 1998; McCaig et al. 1994; Prosser and Embley 2002; Voytek and Ward 1995). AOB are divided into two monophyletic lineages based on their 16S rRNA gene sequences (Head et al. 1993; Purkhold et al. 2000, 2003; Teske et al. 1994). The first lineage belongs to the betaproteobacteria (beta-AOB) and comprises Nitrosomonas (including Nitrosococcus mobilis) and Nitrosospira (including Nitrosolobus and Nitrosovibrio) species. The second lineage, affiliated with the gammaproteobacteria (gammaAOB), contains Nitrosococcus oceani and Nitrosococcus halophilus. The phylogenetic coherence of $\mathrm{AOB}$ has prompted the design of several specific polymerase chain reaction (PCR) primers and fluorescent in situ hybridization (FISH) probes (Hastings et al. 1997; Hiorns et al. 1995; Kowalchuk et al. 1997; McCaig et al. 1994; Mobarry et al. 1996; Pommerening-Roeser et al. 1996; Stephen et al. 1996; Utaker and Nes 1998; Voytek and Ward 1995; Wagner et al. 1995; Ward et al. 1997). However, the 16S rRNA gene sequence similarity is very high (even more than $99 \%$ within the genus Nitrosospira). Sequencing of the intergenic spacer between the $16 \mathrm{~S}$ and the $23 \mathrm{~S}$ rRNA genes has been suggested as an alternative to differentiate closely related species. Differences in size (ranging from ca. 400 to $700 \mathrm{bp}$ ) and lower sequence similarity (43$96 \%$ ) suggested that this is a valuable complementary tool to the 16S rRNA-based approaches (Aakra et al. 1999). However, it has not been widely used for environmental studies.

So far, the study of anammox bacteria in natural assemblages has been usually based on 16S rRNA phylogenetic markers. Like AOB, $16 \mathrm{~S}$ rRNA gene sequence analyses of anammox bacteria show that they form a monophyletic clade within the phylum Planctomycetes. However, a higher 16S rRNA gene sequence divergence has been observed among anammox bacteria $(<87.1 \%$ identity; Schmid et al. 2005; Woebken et al. 2008) compared 
Fig. 1 Phylogenetic tree based on 16S rRNA gene sequences for different ammonia-oxidizing microorganisms. The sequences were aligned with Muscle (Edgar 2004) using a maximum of 24 iterations. A maximumlikelihood tree was built from the resulting alignment with PhyML (Guindon and Gascuel 2003) using the JTT model, 16 substitution rate classes, and maximum-likelihood estimates of parameters. Bootstrap values (\%) from 1,000 bootstraps are indicated

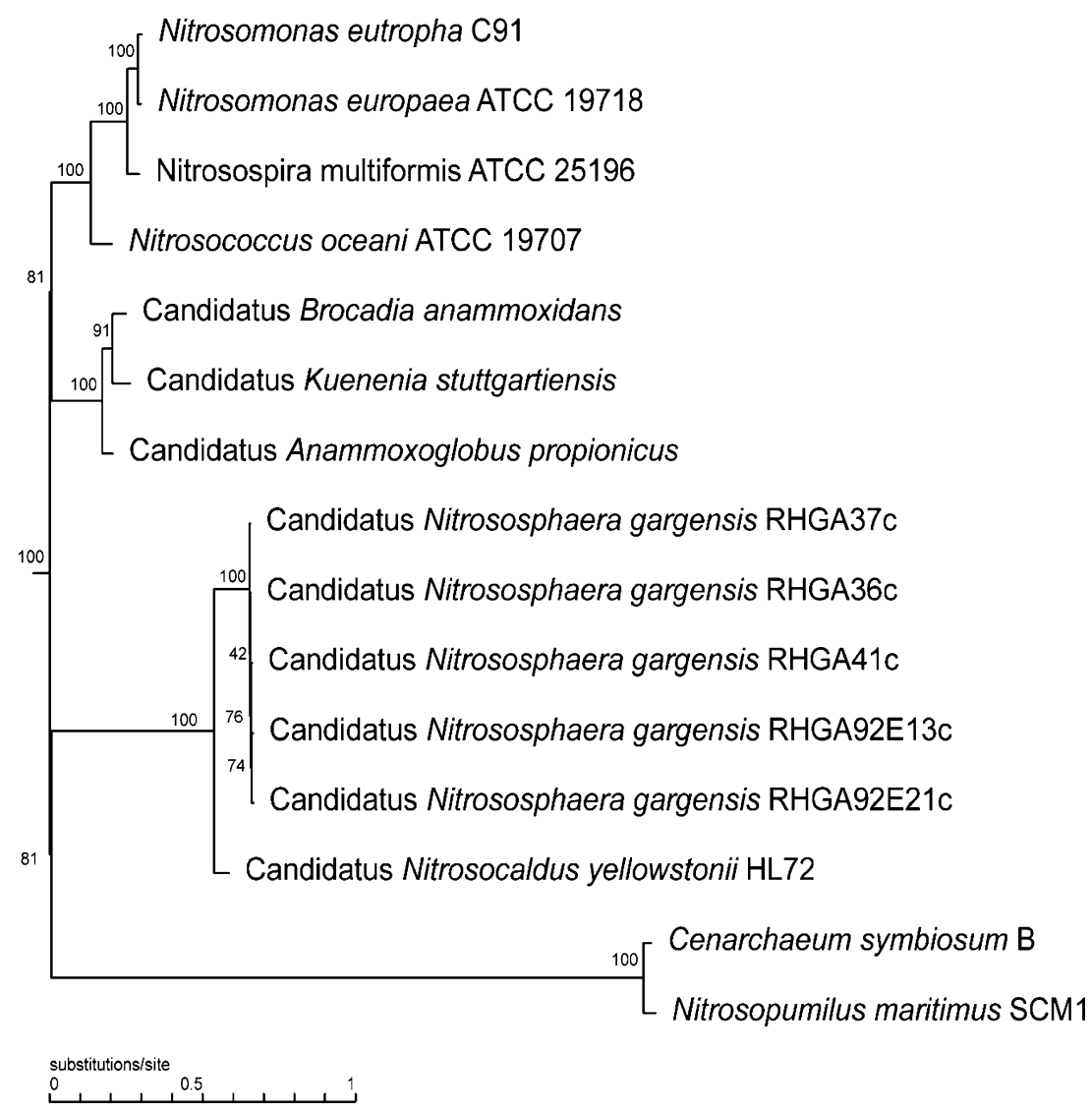

to AOB (<89.5\% similarity; Purkhold et al. 2000). Although amplification with nonspecific $16 \mathrm{~S}$ rRNA gene primers has been used to characterize environmental communities with high abundance of anammox bacteria (e.g., anammox bioreactors), in samples with low representation of anammox, nonspecific 16S rRNA clone libraries are not a good choice. Therefore, some specific primers, mainly derived from FISH probes, have been suggested as an alternative (Schmid et al. 2005). Unlike in other Planctomycetes, in anammox bacteria, the $16 \mathrm{~S}$ rRNA, the $23 \mathrm{~S}$ rRNA, and an intergenic sequence between them are cotranscribed together as an operon. This intergenic sequence has been used for designing FISH probes that can be used for the specific detection of anammox (Schmid et al. 2001). FISH has been particularly useful for the study of these bacteria because of their characteristic doughnut shape generated by the presence of the "anammoxosome", a special compartment of the cell where the anammox process takes place (Schmid et al. 2005).

Up to now, AOA appear not to form a monophyletic clade but rather to belong to different lineages within the Crenarchaeota. The worldwide distribution and numerical importance of Crenarchaeota has been demonstrated in several 16S rRNA gene surveys. Phylogenetic analysis revealed distinct lineages that in general reflect a certain level of ecological differentiation based on the environment
(Nicol and Schleper 2006). Genes that are possibly involved in nitrification have been found among some of these lineages from both soil and aquatic environments. A comparison of diversity studies based on the $16 \mathrm{~S}$ rRNA gene and archaeal amo $A$ indicates a substantial congruence in the phylogeny of crenarchaeal ribosomal and amo genes (Prosser and Nicol 2008). However, the 16S rRNAdefined diversity is significantly greater than the diversity associated with ammonia-oxidizing activity (Nicol and Schleper 2006; Prosser and Nicol 2008). Since it remains unknown whether AOA represent a monophyletic clade, as it is the case for AOB and anammox, the use of specific $16 \mathrm{~S}$ rRNA gene primers for studying AOA is not a promising approach.

\section{Functional markers}

The main pitfall of the $16 \mathrm{~S}$ rRNA gene as a molecular marker is that it is not necessarily related to the physiology of the target organisms (Calvo and GarciaGil 2004; Kowalchuk and Stephen 2001), and a slight lack of specificity may shift the spectrum of sequences amplified by PCR toward phylogenetically related but physiologically and ecologically different organisms (Bothe et al. 2000; Junier et al. 2008a). This is clearly 
the case for AOB (Junier et al. 2008a) and most likely also for AOA and anammox. Another reason for using functional gene markers is that certain microbial guilds (i.e., microorganisms performing a common function) are not numerically dominant, as it is the case for AOM, and are hardly detectable using a 16S rRNA gene-based approach. Therefore, functional markers such as the genes encoding key enzymes involved in a specific metabolic pathway, e.g., ammonia oxidation, have been considered as an alternative for ecological studies (Rotthauwe et al. 1997).

In aerobic $\mathrm{AOB}$ and $\mathrm{AOA}$, ammonium is first oxidized by the membrane-bound enzyme ammonia monooxygenase (Arp et al. 2002; Könneke et al. 2005). In the case of AOB, the second and energy-producing step is the oxidation of hydroxylamine to nitrite by hydroxylamine oxidoreductase (HAO; Arp et al. 2002). In AOA, an alternative mechanism for channeling electrons has been proposed, since available genome information does not support the existence of genes homologous to hao and other essential proteins found in AOB (Hallam et al. 2006a). Like aerobic ammonia oxidizers, anammox bacteria use ammonia oxidation as energy-generating mechanism for autotrophic growth. However, they use nitrite (instead of oxygen) as an electron acceptor. In anammox, a different metabolic pathway combines ammonia oxidation and denitrification (specifically nitrite reduction and $\mathrm{N}_{2}$ production) in a single process (Kartal et al. 2007). Thus, only part of the ammonia oxidation pathway and consequently the potential functional markers derived from it is common to both aerobic and anaerobic AOM. Table 1 gives a summary of the functional molecular markers available for studying AOM in environmental samples.

\section{Ammonia monooxygenase genes}

In all known $\mathrm{AOB}$, the genes encoding the enzyme $\mathrm{AMO}$ belong to an operon with the structure amoCAB (Chain et al. 2003; Klotz et al. 2006; Norton et al. 2002, 2008; Stein et al. 2007). Multiple copies of the operon are present in the genomes of beta-AOB (Chain et al. 2003; Norton et al. 2008; Stein et al. 2007), whereas a single copy has been reported for gamma-AOB (Klotz et al. 2006). Despite the potential of using the whole amoCAB operon for molecular studies, only a portion of the gene amo $A$ has been generally used as a molecular marker to study the diversity of AOB (Rotthauwe et al. 1997). It has been argued that this region, which is relatively short (around $450 \mathrm{bp}$ ) and highly conserved, provides less resolution than the 16S rRNA gene (Koops et al. 2003; Purkhold et al. 2003). For environmental studies, the advantages of the higher specificity of the amoA approach may outweigh this disadvantage.
Since the publication of the first amoA sequence of Nitrosomonas europaea (McTavish et al. 1993), the number of partial and full-length sequences available in public databases has increased significantly (Fig. 2). Several PCR primers to amplify amoA have been published (Holmes et al. 1995; Hoshino et al. 2001; Juretschko et al. 1998; Nicolaisen and Ramsing 2002; Nold et al. 2000; Norton et al. 2002; Okano et al. 2004; Purkhold et al. 2000; Rotthauwe et al. 1997; Stephen et al. 1999; Sinigalliano et al. 1995; Webster et al. 2002), and a recent comparison of these primers has indicated that there are considerable differences in their performance and specificity (Junier et al. 2008b). The analysis of AMO-encoding genes has been extended to $a m o C$ and $a m o B$ (Calvo and Garcia-Gil 2004; Norton et al. 2002; Purkhold et al. 2000). A nested PCR approach to amplify environmental amoCAB sequences has recently been established, providing an increase of the sensitivity in detecting amo genes in samples with low abundances of AOB (Junier et al. 2009).

Interestingly, the genome projects of $N$. europaea (Chain et al. 2003), Nitrosomonas eutropha (Stein et al. 2007), and Nitrosospira multiformis (Norton et al. 2008) have revealed the existence of two additional conserved genes, orf4 and orf5, immediately following the amoCAB operon (Fig. 3). The genomes of $N$. europaea and $N$. multiformis also encode singletons of amoC and orf4/orf5. It has been suggested that these unclustered copies may extend the flexibility for expression of the ammonia catabolic inventory under fluctuating ammonia concentrations (Norton et al. 2008). In the gamma-AOB $N$. oceani, two additional genes, orfl and orf5, have been identified as belonging to the $a m o C A B$ operon. While orf5 is homologous to the orf5 in beta-AOB, orf1 has no equivalent in beta-AOB. Both genes, recently designated $a m o R$ and $a m o D$, respectively, are cotranscribed with amoCAB, forming the specific gamma-AOB amoRCABD operon (El Sheikh et al. 2008), which is specific for gamma-AOB. So far, none of these genes has been used for environmental studies.

As mentioned above, homologs to the amoA gene were initially detected in genomic community studies and cultured AOA (Könneke et al. 2005; Treusch et al. 2005; Venter et al. 2004). Homologs to $a m o C$ and $a m o B$ also have been found, although the structure of an amoCAB operon has not been observed in AOA (Nicol and Schleper 2006). Several primer sets have been developed to amplify archaeal amoA (Francis et al. 2005; Könneke et al. 2005; Park et al. 2008; Tourna et al. 2008; Treusch et al. 2005; Urakawa et al. 2008), allowing the identification and quantification of AOA (Beman et al. 2008; Mincer et al. 2007). Currently, archaeal amo $A$ sequences are submitted to the GenBank at a faster pace than bacterial amoA sequences (Fig. 2). 
Table 1 Summary of functional molecular markers used to study ammonia-oxidizing microorganisms in environmental samples

\begin{tabular}{|c|c|c|c|c|c|}
\hline Enzyme & Gene & Group & Primer & Sequence $\left(5^{\prime}-3^{\prime}\right)$ & Reference \\
\hline \multirow[t]{42}{*}{ AMO } & \multirow[t]{42}{*}{ amoA } & \multirow[t]{28}{*}{ Bacteria } & amoA21f(AMO-F2) & AGA AAT CCT GAA AGC GGC & Sinigalliano et al. (1995) \\
\hline & & & amoA34f & $\begin{array}{l}\text { GCG GCR AAA ATG CCG CCG } \\
\text { GAA GCG }\end{array}$ & Molina et al. (2007) \\
\hline & & & amoA4Of (AMO-F2) & AAG ATG CCG CCG GAA GC & Juretschko et al. (1998) \\
\hline & & & amoA49f & GAG GAA GCT GCT AAA GTC & Junier et al. (2008b) \\
\hline & & & amoA60r (304R) & $\begin{array}{l}\text { TAY CGC TTC CGG CGG CAT } \\
\text { TTT CGC CGC }\end{array}$ & Norton et al. (2002) \\
\hline & & & amoA121f (amoA-3F) & ACC TAC CAC ATG CAC TT & Webster et al. (2002) \\
\hline & & & amoA151f (A189) & GGN GAC TGG GAC TTCTGG & Holmes et al. (1995) \\
\hline & & & amoA154f (301F) & $\begin{array}{l}\text { GAC TGG GAC TTC TGG CTG } \\
\text { GAC TGG AA }\end{array}$ & Norton et al. (2002) \\
\hline & & & AmoA154fs & GAC TGG GAC TTC TGG & Junier et al. (2008b) \\
\hline & & & AmoA187f (amoA-1FF) & CAA TGG TGG CCG GTT GT & Hoshino et al. (2001) \\
\hline & & & amoA310f (amoA-3F) & CGT GAG TGG GYT AAC MG & Purkhold et al. (2000) \\
\hline & & & amoA332f (amoA-1F) & GGG GTT TCT ACT GGT GGT & Rotthauwe et al. (1997) \\
\hline & & & $\begin{array}{l}\operatorname{amoA332fHY} \\
\text { (amoA1F mod) }\end{array}$ & GGG GHT TYT ACT GGT GGT & Stephen et al. (1999) \\
\hline & & & amoA337p (A337) & $\begin{array}{l}\text { TTC TAC TGG TGG TCR CAC } \\
\text { TAC CCC ATC AAC T }\end{array}$ & Okano et al. (2004) \\
\hline & & & amoA349r & ACC ACC AGT AGA AAC CCC & Junier et al. (2009) \\
\hline & & & amoA359rC (amoA-4R) & GGG TAG TGC GAC CAC CAG TA & Webster et al. (2002) \\
\hline & & & amoA627r & CGT ACC TTT TTC AAC CAT CC & Junier et al. (2008b) \\
\hline & & & amoA664f & GCS TTC TTC TCN GCS TTTC & Junier et al. (2009) \\
\hline & & & amoA665r (AMO-R2) & GCT GCA ATA ACT GTG GTA & Juretschko et al. (1998) \\
\hline & & & amoA680r (A682 mod) & AAV GCV GAG AAG AAW GC & Nold et al. (2000) \\
\hline & & & $\operatorname{amoA681r}(\mathrm{A} 682)$ & GAA SGC NGA GAA GAA SGC & Holmes et al. (1995) \\
\hline & & & amoA686r (AMO-R) & GAT ACG AAC GCA GAG AAG & Sinigalliano et al. (1995) \\
\hline & & & amoA802f & $\begin{array}{l}\text { GAA GAA GGC TTT SCM GAG } \\
\text { GGG }\end{array}$ & Junier et al. (2009) \\
\hline & & & amoA820r (Amoa-2R') & CCT CKG SAA AGC CTT CTT C & Okano et al. (2004) \\
\hline & & & amoA822r (amoA-2R) & CCC CTC KGS AAA GCC TTC TTC & Rotthauwe et al. (1997) \\
\hline & & & $\begin{array}{l}\text { amoA822rTC } \\
(\text { amoA-2R-TC) }\end{array}$ & CCC CTC TGC AAA GCC TTC TTC & Nicolaisen and Ramsing (2002) \\
\hline & & & $\begin{array}{l}\text { amoA822rTG } \\
\text { (amoA-2R-TG) }\end{array}$ & CCC CTC TGG AAA GCC TTC TTC & Okano et al. (2004) \\
\hline & & & amoA828r (302R) & $\begin{array}{l}\text { TTT GAT CCC CTC TGG AAA GCC } \\
\text { TTC TTC }\end{array}$ & Norton et al. (2002) \\
\hline & & \multirow[t]{14}{*}{ Archaea } & Arch-amoAF & STA ATG GTC TGG CTT AGA CG & Francis et al. (2005) \\
\hline & & & Arch-amoAR & GCG GCC ATC CAT CTG TAT GT & Francis et al. (2005) \\
\hline & & & amo196F & GGW GTK CCR GGR ACW GCM & Treusch et al. (2005) \\
\hline & & & amo227R & CRA TGA AGT CRT AHG GRT ADC C & Treusch et al. (2005) \\
\hline & & & amo247 & $\begin{array}{l}\text { CCA ACC AWG CWC CYT TKG CDA } \\
\text { CCC }\end{array}$ & Treusch et al. (2005) \\
\hline & & & CrenAmo1F & AAT GGT CTG GCT WAG ACG C & Könneke et al. (2005) \\
\hline & & & CrenAmo1R & GAC CAR GCG GCC ATC CA & Könneke et al. (2005) \\
\hline & & & crenAMO_F & ATG GTC TGG CTA AGA CGM TGT A & Hallam et al. (2006b) \\
\hline & & & cren AMO_F & CCC ACT TTG ACC AAG CGG CCA T & Hallam et al. (2006b) \\
\hline & & & Arch-amoA26F & $\begin{array}{l}\text { GAC TAC ATM TTC TAY ACW GAY } \\
\text { TGG GC }\end{array}$ & Park et al. (2008) \\
\hline & & & Arch-amoA417R & $\begin{array}{l}\text { GGK GTC ATR TAT GGW GGY AAY } \\
\text { GTT GG }\end{array}$ & Park et al. (2008) \\
\hline & & & CG I.1b-amoAF & ATA GTT GTA GTT GCT GTA AAT AG & Park et al. (2008) \\
\hline & & & CG I.1b-amAR & CTC TAG AGG GTC TCT GAC CAG & Park et al. (2008) \\
\hline & & & Arch-amoAF & GCT CTA AAT ATG ACA GTA TAC & Park et al. (2008) \\
\hline
\end{tabular}


Table 1 (continued)

\begin{tabular}{|c|c|c|c|c|c|}
\hline Enzyme & Gene & Group & Primer & Sequence $\left(5^{\prime}-3^{\prime}\right)$ & Reference \\
\hline & & & Arch-amoAR & AYC ATG TTG AAY AAT GGT AAT GAC & Park et al. (2008) \\
\hline & & & CG I.1b-amoAF & GTA CAT TAT TGA CAA TCA ACG C & Park et al. (2008) \\
\hline & & & CG I.1b-amoAR & ATC CTA RYG CAA ACC AAG CTC & Park et al. (2008) \\
\hline & & & CrenamoA616r & GCC ATC CAT CTG TAT GTC CA & Tourna et al. (2008) \\
\hline & & & Arch-amoA-79F & ATT AAY GCA GGW GAY TAY A & Urakawa et al. (2008) \\
\hline & & & Arch-amoA-479R & TAT GGT GGY AAY GTD GGT C & Urakawa et al. (2008) \\
\hline & & & Arch-amoA-479R & AAT GGT CTG GST TAG AMG & de la Torre et al. (2008) \\
\hline & $a m o B$ & Bacteria & amoB44r (amoB-4R) & GCT AGC CAC TTT CTG G & Purkhold et al. (2000) \\
\hline & & & amoB160 (amoBMf) & TGG TAY GAC ATK AWA TGG & Calvo and Garcia-Gil (2004) \\
\hline & & & amoB506r (308R) & $\begin{array}{l}\text { TCC CAG CTK CCG GTR ATG TTC } \\
\text { ATC C }\end{array}$ & Norton et al. (2002) \\
\hline & & & amoB660r (amoBMr) & RCG SGG CAR GAA CAT SGG & Calvo and Garcia-Gil (2004) \\
\hline & & & amoB1179r & CCA AAR CGR CTT TCC GG & Junier et al. (2008b) \\
\hline & & & amoB1179rGam & GCA AAG CGG CTG TCT GG & Junier et al. (2008b) \\
\hline & & Archaea & CrenAmo2.1F & CAC GGT GTM CAA GCA CA & Könneke et al. (2005) \\
\hline & & & CrenAmo2.2R & RAT TAC YTG CCA VGG TC & Könneke et al. (2005) \\
\hline & amoC & Bacteria & amoC58f & CTA YGA CAT GTC RTC GTG G & Junier et al. $(2008 \mathrm{a}, \mathrm{b})$ \\
\hline & & & $\operatorname{amoC} 763 \mathrm{f}(305 \mathrm{~F})$ & GTG GTT TGG AAC RGI CAR AGC AAA & Norton et al. (2002) \\
\hline & & Archaea & CrenAmo3.1F & ATG GCA CAR ATG CCS GC & Könneke et al. (2005) \\
\hline & & & CrenAmo3R & GGT ATW GAT CTG TAC AA & Könneke et al. (2005) \\
\hline \multirow[t]{4}{*}{ HAO } & hao & Bacteria & haof1 & TGC GTG GAR TGY CAC & Schmid et al. (2008) \\
\hline & & & haoR3 & AGR TAR GAK YSG GCA AA & Schmid et al. (2008) \\
\hline & & & haoF4 & AAY CTK CGC TCR ATG GG & Schmid et al. (2008) \\
\hline & & & haoR2 & GGT TGG TYT TCT GKC CGG & Schmid et al. (2008) \\
\hline \multirow[t]{10}{*}{$\mathrm{HZO}$} & hzo & Anammox & hzocl1F1 & TGY AAG ACY TGY CAY TGG & Schmid et al. (2008) \\
\hline & & & hzocl1R2 & ACT CCA GAT RTG CTG ACC & Schmid et al. (2008) \\
\hline & & & hzo1F11 & TGY AAG ACY TGY CAY TGG G & Schmid et al. (2008) \\
\hline & & & hzocl1R2 & ACT CCA GAT RTG CTG ACC & Schmid et al. (2008) \\
\hline & & & hzocl2aF1 & GGT TGY CAC ACA AGG C & Schmid et al.(2008) \\
\hline & & & hzocl2aR1 & TYW ACC TGG AAC ATA CCC & Schmid et al. (2008) \\
\hline & & & hzocl2aF1 & GGT TGY CAC ACA AGG C & Schmid et al. (2008) \\
\hline & & & hzocl2aR2 & ATA TTC ACC ATG YTT CCA G & Schmid et al. (2008) \\
\hline & & & hzocl2aF2 & GTT GTG MTG MWT GTC ATG G & Schmid et al. (2008) \\
\hline & & & hzocl2aR1 & TYW ACC TGG AAC ATA CCC & Schmid et al. (2008) \\
\hline \multirow[t]{4}{*}{ Nitrite reductase } & $\operatorname{nirK}$ & Bacteria & Cunir3 & CGT CTA YCA YTC CGC VCC & Casciotti and Ward (2001) \\
\hline & & & Cunir4 & GCC TCG ATC AGR TTR TGG & Casciotti and Ward (2001) \\
\hline & $\operatorname{nir} S$ & Anammox & Scnir372F & TGT AGC CAG CAT TGT AGC GT & Lam et al. (2009) \\
\hline & & & Scnir845R & TCA AGC CAG AC CAT TTG CT & Lam et al. (2009) \\
\hline \multirow[t]{6}{*}{ NorB } & norB & Bacteria & norB1 & CGN GAR TTY CTS GAR CAR CC & Casciotti and Ward (2005) \\
\hline & & & norB2 & GAC AAR HWY TAY TGG TGG T & Casciotti and Ward (2005) \\
\hline & & & norB3 & CCY TCV ACC CAG ASA TGC AC & Casciotti and Ward (2005) \\
\hline & & & norB6 & TGC AKS ARR CCC CAB ACB CC & Casciotti and Ward (2005) \\
\hline & & & norB7 & CCR TGG STR WAR WAR TTS AC & Casciotti and Ward (2005) \\
\hline & & & norB8 & CRT ADG CVC CRW AGA AVG C & Casciotti and Ward (2005) \\
\hline \multirow[t]{2}{*}{ Accase } & $a c c B$ & Archaea & ACAC254f & GCT GAT GCT ATA CAT CCW GGW TAY & Auguet et al. (2008) \\
\hline & & & ACAC720r & GCT GGA GAT GGA GCY TCY TCW ATT & Auguet et al. (2008) \\
\hline
\end{tabular}

$A M O$ ammonia monooxygenase, $H A O$ hydroxylamine oxidoreductase, $H Z O$ hydrazine oxidoreductase, Nor $B$ nitric oxide reductase, $A C C a s e$ biotin carboxylase 
Fig. 2 Cumulative number of amoCAB/hao sequences submitted to the GenBank database.

a amoA and hao/hzo genes.

b $a m o B$ and $a m o C$ a

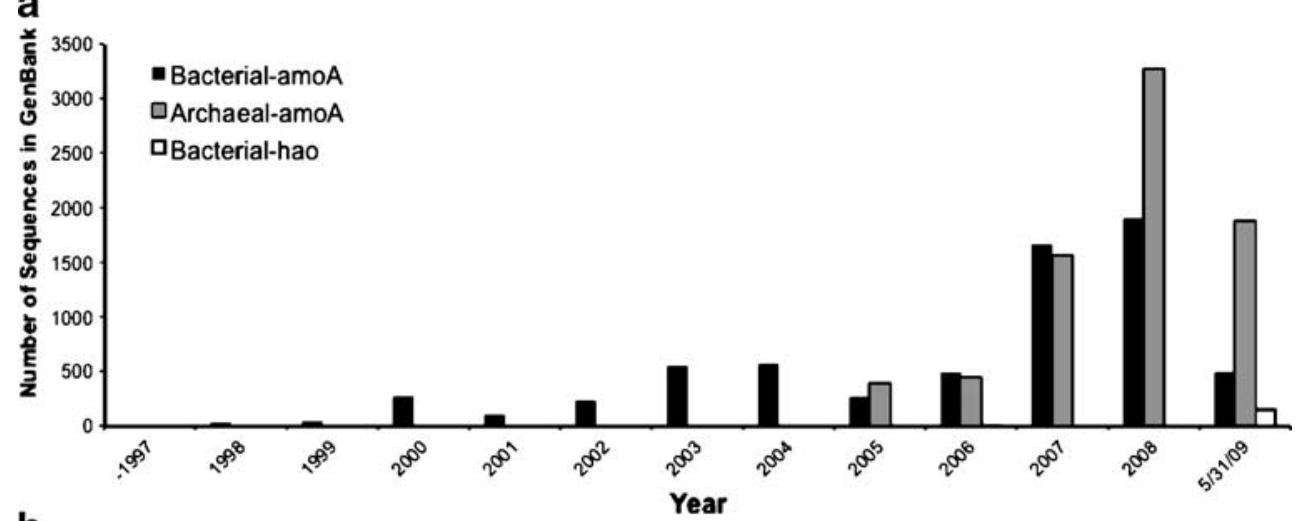

b

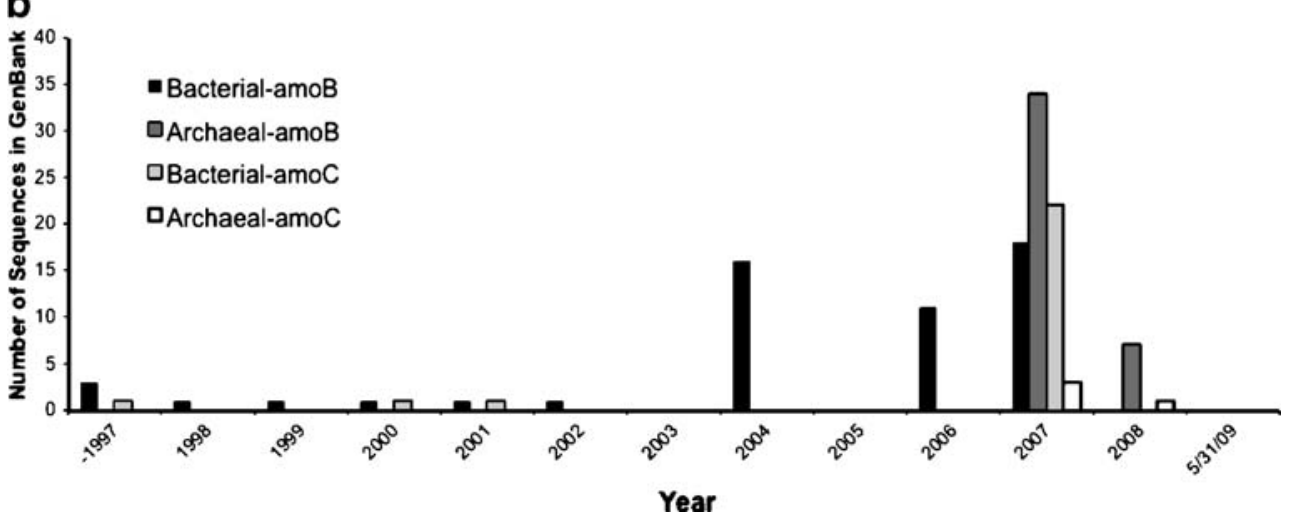

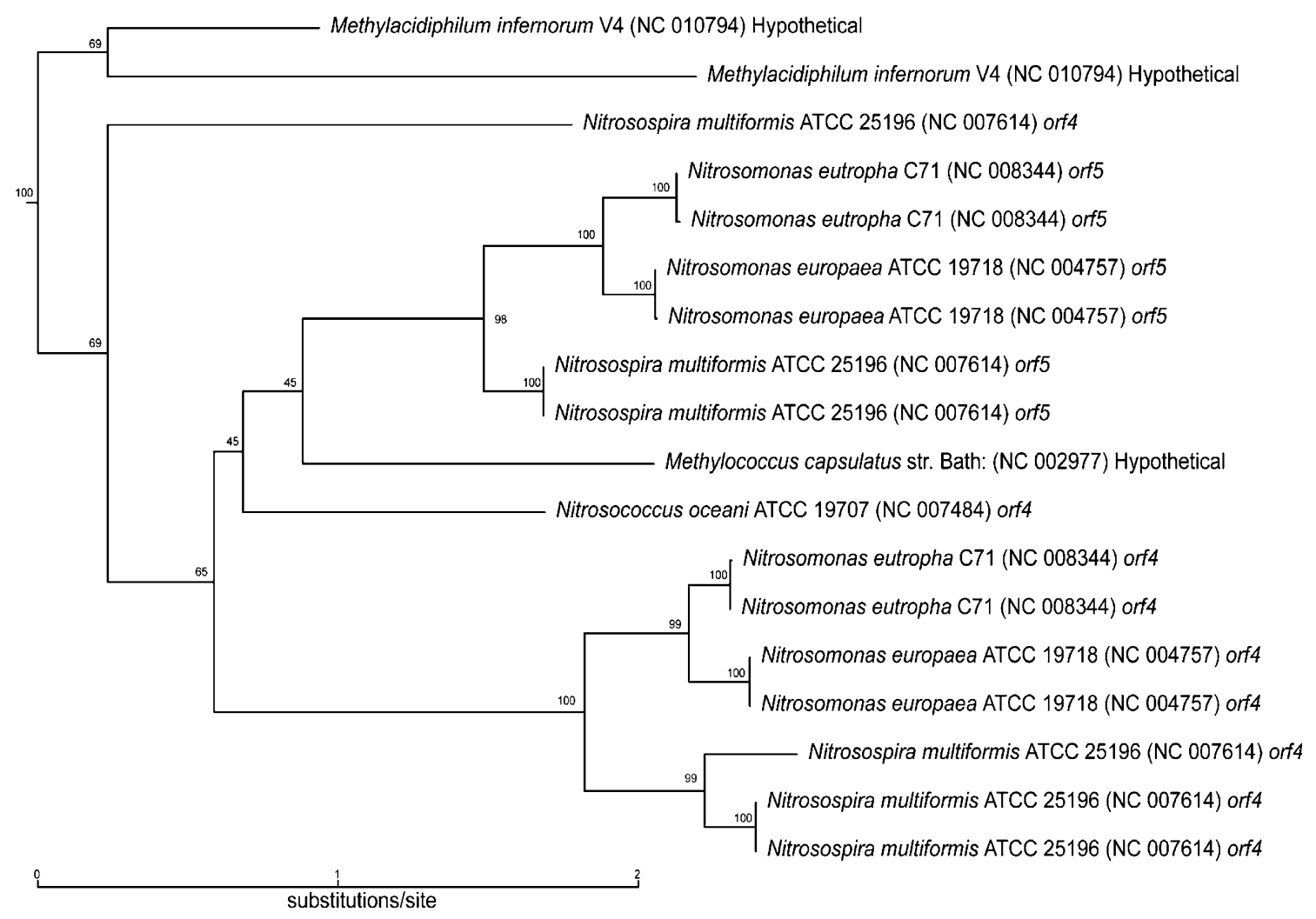

Fig. 3 Phylogenetic tree based on sequences homologs to orf4 and orf5 found in the genome of ammonia-oxidizing bacteria and methaneoxidizing bacteria. For methods, see Fig. 1 
Hydroxylamine/hydrazine oxidoreductase genes in aerobic and anaerobic ammonia-oxidizing bacteria

One of the few potentially common functional markers for aerobic and anaerobic ammonia-oxidizing bacteria is the gene encoding the octahaem cytochrome c (OCC) proteins, hydroxylamine oxidoreductase in $\mathrm{AOB}$, and hydrazine oxidoreductase (HZO) in anammox. HAO is responsible for the dehydrogenation of hydroxylamine to nitrite (the second step of ammonia oxidation) and is proposed as the protein relaying the electrons to the ubiquinone pool via two interacting cytochromes, $c 554$ and $c M 552$ (Hooper et al. 2005). Due to its soluble nature, HAO is the best-studied functional component of aerobic ammonia oxidation (Igarashi et al. 1997). In anammox, HZO converts hydrazine to $N_{2}$ (Strous et al. 2006), generating the proton motive force for energy production. HAO and HZO can oxidize the alternate substrate (hydroxylamine and hydrazine, respectively; Hooper et al. 2005), and functional and sequence similarities between both enzymes have been described (Klotz et al. 2008; Shimamura et al. 2007; Strous et al. 2006).

Multiple copies of the hao gene have been revealed in the genome sequencing projects of beta-AOB (Arp et al. 2007; Chain et al. 2003; Norton et al. 2008; Stein et al. 2007), as part of a gene cluster including three additional genes, orf 2 and $c y c A B$ (although $c y c B$ is absent in one of the copies in $N$. europaea and $N$. eutropha (Norton et al. 2008)). The genome analysis of Candidatus Kuenenia stuttgartiensis revealed eight highly divergent octahaem protein regions as possible candidates for HZO (Strous et al. 2006). The genes encoding the HAO/HZO proteins appear to be suitable as functional and phylogenetic biomarkers because of their highly conserved sequence across different species (Klotz et al. 2008), and recently, several sets of degenerate primers were designed based on the available hao/hzo sequences (Schmid et al. 2008).

Phylogenetic analyses of the hao/HAO sequences obtained with a collection of cultured representatives of AOB were congruent with those reported for the 16S rRNA gene and amoA/AmoA (Schmid et al. 2008), suggesting that the hao gene may be an alternative molecular marker for AOB. However, the hao gene is also present in nonammonia oxidizers, including methane-oxidizing bacteria (MOB) and other microorganisms (Ward et al. 2004, Bergmann et al. 2005). The in silico analysis of the degenerate primers designed to amplify hao (Schmid et al. 2008) suggested that they are specific for $\mathrm{AOB}$, although stringent conditions are required to avoid cross-amplification with non-AOB also containing hao copies (e.g., MOB and the sulfur oxidizer Silicibacter pomeroyi; Moran et al. 2004).

Analysis of the $h z o$ genes from anammox proved to be more complex than in the case of hao for AOB since in the genome of Candidatus K. stuttgartiensis, several possible
OCC protein-encoding genes were identified (Strous et al, 2006). The phylogeny of $h z o / \mathrm{HZO}$ revealed the existence of three clusters of sequences. At least one of these, cluster 1 , is in agreement with the previously published rRNA phylogeny of anammox bacteria. The analyses of the primers with cultures, man-made, and environmental samples produced positive results opening the promise of the use of $h z o$ as a phylogenetic and functional marker in the future (Schmid et al. 2008).

\section{Other potential candidates for functional markers}

Genes involved in nitrogen metabolism

Other genes encoding enzymes involved in the nitrogen metabolism have been found in AOB (Arp et al. 2007). One of these genes, the copper-containing dissimilatory nitrite reductase gene (nirK), was detected in several isolates of beta-AOB by PCR with nonspecific primers (Casciotti and Ward 2001). The topology of the nirK tree corresponds to those of 16S rRNA and amoA. These results suggest that nirK sequences retrieved from the environment may include sequences from ammonia-oxidizing bacteria, although specific nirK-AOB primers have not been designed yet. Another gene that has been shown to be present in some $\mathrm{AOB}$ is the one encoding for the large subunit of nitric oxide reductase (norB). However, amplification was not successful in all Nitrosospira strains tested (Casciotti and Ward 2005), and therefore, it is not clear if it is useful as a general functional marker of AOB.

A putative nitrite reductase (nirS) gene coding for cytochrome $c d-1$ was also found in anammox. NirS is postulated to participate in the oxidation of nitrite to nitric oxide, which forms hydrazine together with ammonium in a process catalyzed by the hydrazine hydrolase (Strous et al. 2006). This putative nirS has been used as molecular marker to study the presence and potential activity of anammox in the environment by reverse transcriptase PCR (Lam et al. 2009).

Autotrophic growth

Although autotrophy is one of the features common to AOM and most $\mathrm{AOB}$, heterotrophic growth has been reported for several AOB (Arp et al. 2007). In the case of AOB, the genes coding the ribulose-biphosphate carboxylase/oxygenase (RuBisCO, $c b b L$ and $c b b S$ ) could be considered as a molecular marker. However, evidence from the genome projects of $\mathrm{AOB}$ indicate that the $c b b$ operon has been subjected to horizontal gene transfer (Norton et al. 2008). The genes for RuBisCO do not appear to be present in AOA and anammox. 
In AOA, genes corresponding to the 3-hydroxypropionate and citric acid cycles were identified (Hallam et al. 2006a). One of the enzymes responsible for the fixation of $\mathrm{CO}_{2}$ in this metabolic pathway is the acetyl CoA carboxylase (ACCase). The gene $a c c B$ encoding the biotin carboxylase, one of the three subunits of the ACCase, has been proposed as a potential molecular marker to investigate $\mathrm{CO}_{2}$ assimilation linked to archaeal autotrophy (Auguet et al. 2008).

In anammox, the complete acetyl CoA pathway was detected in the genome of Candidatus $K$. stuttgartiensis (Strous et al. 2006). However, so far, none of the genes involved in $\mathrm{CO}_{2}$ assimilation have been used as molecular markers for ecological studies of anammox.

\section{Application examples from different environments}

\section{Ammonia-oxidizing bacteria}

The community structure of AOB has been investigated in a wide spectrum of environments. Most studied environments are soils, where $\mathrm{pH}$ was found to have a considerable effect on the activity of AOB communities and on the biogeochemical processes that they mediate. Experimentally, it has been demonstrated that ammonia oxidation rarely occurs at $\mathrm{pH}$ values lower than 7 (Burton and Prosser 2001; Gieseke et al. 2006). However, a series of studies revealed different niches for different groups of AOB (and also AOA) in soils with $\mathrm{pH}$ between 4.5 and 7.5 (Nicol et al. 2008). For example, a tendency toward the dominance of Nitrosospira cluster 3 in agricultural soils with neutral $\mathrm{pH}$ versus Nitrosospira cluster 2 in acidic soils has been observed using the 16S rRNA gene (Kowalchuk et al. 1997; Stephen et al. 1996) or amoA (Nugroho et al. 2007). A combination of $16 \mathrm{~S}$ rRNA gene and amo $A$ profiling has been also used to characterize the structure and abundance of AOB in response to the variation of soil management. Using this approach, the dominance of Nitrosospira cluster 3 and 4 was found in soils regardless of the amendment with low, medium, or high concentrations of ammonia (Avrahami et al. 2002; Schmidt et al. 2007).

The study of AOB in marine ecosystems initially carried out using $16 \mathrm{~S}$ rRNA gene markers has shown that these microorganisms are widespread in coastal, open ocean, and even polar environments (Hollibaugh et al. 2002; O'Mullan and Ward 2005; Phillips et al. 1999), including oxygendeficient water columns and anoxic sediments (Kim et al. 2006; Molina et al. 2007). 16S rRNA gene surveys in the water column reveal a niche differentiation of certain genera within the beta-AOB with the predominance of Nitrosomonas spp. in attached surfaces (particle-associated) and of Nitrosospira spp. as free-living microorganisms (Phillips et al. 1999). Studies using amoA as molecular marker also indicate the dominance of sequences associated to Nitrosospira spp. and particularly affiliated to a yetuncultured Clade 1 (Freitag and Prosser 2004; Hollibaugh et al. 2002; Kim et al. 2008; Molina et al. 2007).

AOB also have been studied in extreme environments. Culture-based studies indicate a broad distribution of salttolerant and halophilic species of AOB. Molecular studies based on $16 \mathrm{~S}$ rRNA and amo $A$ in different hypersaline environments revealed communities dominated by $N$. europaea and $N$. eutropha in Mono Lake (Carini and Joye 2008; Ward et al. 2000), Nitrosomonas halophila, Nitrosomonas marina, Nitrosomonas communis in Salar de Huasco (Dorador et al. 2008), and by different Nitrosomonas and Nitrosospira species in Qinghai Lake (Jiang et al. 2009). Gamma-AOB have not been found in hypersaline environments using the described $16 \mathrm{~S}$ rRNA gene primers, which could indicate the unspecific nature of these primers for nonmarine environmental samples. Since decades, it is well known that nitrification can occur at low temperatures in natural environments (Jones and Morita 1985; Jones et al. 1988). AOB communities in Antarctica analyzed by use of the $16 \mathrm{~S}$ rRNA gene revealed a community composed by mainly two clusters: Nitrosomonas-like sequences and Nitrosospira-like sequences (Bano and Hollibaugh 2000; Hollibaugh et al. 2002). Also, pioneering studies on nitrification at high temperatures described a community dominated by Nitrosospira-like sequences identified by immunofluorescence labeling (Lebedeva et al. 2005). The recovery of amoA sequences from an acidic hot spring in a Japanese gold mine revealed the broad adaptability of certain AOB, highly similar to Nitrosomonas sp. Nm107 and $N$. nitrosa, to extreme conditions (Hirayama et al. 2005).

Anaerobic ammonia-oxidizing bacteria (anammox)

Using the 16S RNA phylogenetic marker by means of FISH and PCR-dependent techniques, researchers detected anammox in freshwater and marine environments, in soils, wetlands, and wastewater treatment plants. Despite the ubiquity of anammox in nature, a very low diversity has been reported in suboxic and anoxic aquatic ecosystems being mostly dominated by organisms belonging to Candidatus Scalindua spp. (Penton et al. 2006). However, a higher microdiversity was observed in oxygen minimum zones of the ocean (Galan et al. 2009; Woebken et al. 2009) and in man-made environments, where most candidate genera have been discovered, i.e., Candidatus Brocadia, Candidatus Kuenenia, Candidatus Anammoxoglobus (Schmid et al. 2005).

The anammox process is probably widespread in aquatic systems and is not limited to marine or brackish environments. In stratified lake chemoclines, sediment-water 
interfaces and benthic boundary layers, the co-existence of ammonia, nitrite, and nitrate creates potentially suitable niches for anammox bacteria. Schubert et al. (2006) were the first to demonstrate the anammox process in the suboxic water column of Lake Tanganyika, incubating ${ }^{15} \mathrm{NO}_{3}$ labeled water samples in situ. The ${ }^{29} \mathrm{~N}_{2}$ (anammox product) was recorded at all anoxic depths corresponding to $9-13 \%$ of total $\mathrm{N}_{2}$ production in the lake. Presence of anammox bacteria $(0.1-1.4 \%$ of total 4',6-diamidino-2-phenylindolestained bacteria) was confirmed at maximum anammox activity depths using FISH. Phylogenetic analysis of partial 16S rRNA gene sequences resulted in hits close to Candidatus Scalindua brodae and Candidatus Scalindua sorokinii (Schubert et al. 2006). The presence and distribution of anammox 16S rRNA gene sequences in shallow organic rich freshwater sediments from Wintergreen Lake and from wetlands in the Florida Everglades were demonstrated using specific primers (Brod541F/Brod 1260R and An7F/ An1388R) serving as molecular markers for better tracking of anammox bacterial populations. The results suggest that anammox bacteria are agents of nitrogen removal from freshwater lakes besides denitrification (Penton et al. 2006).

Although many scientists have contributed to the knowledge of anammox in aquatic systems, so far they have been less studied in soils and extreme environments. There is a single report of anammox in mangrove soil (Wickramasinghe et al. 2009). 16S rRNA gene clonal sequences analyzed in this study represented novel lineages related to anammox. A less significant role of this process was suggested in saline tidal marsh sediments compared to a freshwater marsh (Koop-Jakobsen and Giblin 2009). Candidatus Brocadia anammoxidans is capable of growing at $43^{\circ} \mathrm{C}$ in the laboratory (Strous et al. 1999); nevertheless, there is little evidence of anammox in hot natural environments. Recently, the occurrence of anammox in hydrothermal vents was established using 16S rRNA gene sequences and lipids as markers (Byrne et al. 2009). Also, 16S rRNA gene sequences recovered from an acidic hot spring were highly similar to those of Candidatus Brocadia anammooxidans (Hirayama et al. 2005).

Ammonia-oxidizing archaea

The recovery of putative amo genes in crenarchaeal DNA from genomic surveys (Treusch et al. 2005; Venter et al. 2004) and the detection of the genes amoA, amoB, and amoC in the uncultivated crenarchaeal symbiont Cenarchaeum symbiosum (Hallam et al. 2006b) open the possibility for a potential role in autotrophic oxidation of ammonia for the highly abundant Crenarchaeota inhabiting the oceans (DeLong 1992, 1998; Fuhrman et al. 1992; Karner et al. 2001), terrestrial (Ochsenreiter et al. 2003), and several other nonextreme environments (Auguet and Casamayor 2008; Perreault et al. 2007). In addition, studies dealing with the amplification of archaeal amoA demonstrated the ubiquitous presence of $\mathrm{AOA}$ in marine, freshwater, and terrestrial environments showing an apparent niche adaptation to different habitats (Erguder et al. 2009; Francis et al. 2005). The quantification of bacterial and archaeal amo $A$ gene copies indicated that AOA outnumbered $\mathrm{AOB}$ in most marine and terrestrial ecosystems by a factor of 10 to 1,000 (Beman et al. 2008; Leininger et al. 2006; Wuchter et al. 2006), suggesting a possible higher contribution to nitrification.

AOA also have been detected in extreme environments: 16S rRNA gene and crenarchaeal amoA sequences related to $N$. maritimus have been recovered from different cold environments like mountain lakes (Dorador 2007; Jiang et al. 2009) and deep-sea waters (Tamegai et al. 2007). Using amoA, archaeal nitrification capability was detected in a series of terrestrial hot springs of Kamchatka, Siberia, and Iceland at temperatures between $82^{\circ} \mathrm{C}$ and $97^{\circ} \mathrm{C}$ and $\mathrm{pH}$ below 7 (Reigstad et al. 2008). The recent cultivation of a thermophilic nitrifier (Candidatus N. yellowstonii), an autotrophic crenarchaeote growing at up to $74^{\circ} \mathrm{C}$ by aerobic ammonia oxidation (de la Torre et al. 2008), as well as the moderate thermophilic Candidatus $N$. gargensis (Hatzenpichler et al. 2008), confirms the possible presence of nitrifying activity due to AOA at high temperature habitats. In recent studies, sequences related to AOA were also found in saline systems like the Salar de Huasco in the Chilean Altiplano (Dorador 2007) and Qinghai Lake in the Tibet (Jiang et al. 2009). In some of these extreme habitats, AOA can be more abundant than AOB (Jiang et al. 2009).

\section{Ammonia-oxidizing microorganisms in biotechnological applications}

Deterioration of water quality by excessive input of organic nitrogen is a very serious environmental concern. The removal of ammonium is of special interest because it can be toxic to aquatic species (Khin and Annachhatre 2004). Because biological nitrogen removal is very cost-effective, the use of AOM for biotechnological applications involving the removal of ammonium has been widely adopted.

Conventional microbial nitrogen removal is based on the oxidation of ammonia and nitrite by $\mathrm{AOB}$ and nitriteoxidizing bacteria, respectively, followed by the reduction of nitrate by heterotrophic denitrifying bacteria. Community analyses based on 16S rRNA and amoA genes to detect ammonia-oxidizing bacteria in wastewater treatment plants (WWTPs) have demonstrated that populations related to Nitrosomonas, including phylogenetic lineages with no cultured representatives, can be responsible for ammonia 
oxidation in these systems (Hallin et al. 2005; Siripong and Rittmann 2007; Wagner and Loy 2002). Quantitative approaches have been implemented using amo $A$ as target to quantify specific populations of AOB in WWTP (Dionisi et al. 2002a, b) and to study the dynamics of different AOB populations overtime (Layton et al. 2005). Quantification based on FISH has also been used to estimate the active populations of AOB in bioreactors (Gieseke et al. 2001).

The effects of environmental conditions such as high ammonium concentrations, different $\mathrm{pH}$ values, and different oxygen concentrations on nitrification and the community structure of AOB in wastewater have also been investigated (Princic et al. 1998). The results indicated that a high ammonium level result in a greater change in community structure, whereas the smaller changes in community structure originated by $\mathrm{pH}$ changes were irreversible. Sequence analysis revealed that $N$. eutropha-like AOB were stimulated at the highest ammonium concentration (Princic et al. 1998).

Anammox represents an alternative $\mathrm{N}_{2}$-producing process to oxidize ammonium under strict anaerobic conditions. The anammox reaction has as advantages the reduction in energy requirements (e.g., to supply oxygen for nitrification), total reduction of carbon requirements, and a decreased biomass yield (Sliekers et al. 2003; van Dongen et al. 2001). All these make anammox a cost-effective and environmentally friendly $\mathrm{N}$-removal system that can reach maximal removal rates of $9 \mathrm{~kg} \mathrm{Nm}^{-3}$ day $^{-1}$ (Jetten et al. 2005; Kartal et al. 2006; Op den Camp et al. 2006). Anammox bacteria were initially and are still enriched from many types of wastewater sludge and probably are indigenous to treatment plants worldwide (Schmid et al. 2005; Op den Camp et al. 2006). The application of enrichment techniques coupled to FISH using specific 16S rRNA gene probes and clone libraries has been essential to reveal the diversity of anammox bacteria in man-made systems (Op den Camp et al. 2006).

In WWTPs, anammox have the potential to replace the conventional denitrification step if preceded by partial nitrification to nitrite as was demonstrated by the implementation of the single reactor system for high ammonium removal over nitrite and completely autotrophic N-removal over nitrite (CANON) bioreactors (Hellinga et al. 1998; Mulder et al. 2001; Sliekers et al. 2003; van der Star et al. 2007). The CANON reactor utilizes the activity of autotrophic aerobic and anaerobic ammonium-oxidizing bacteria to remove ammonium. The nitrite that is produced from the activity of aerobic ammonium oxidizers could be used to remove ammonium from groundwater or other water sources that are low in organic carbon (Third et al. 2001, 2005). Other systems that take advantage of the metabolism of anammox bacteria are the upflow anaerobic sludge bed and sequencing batch reactors (Ahn et al. 2004;
Kartal et al. 2006). In all the cases, the pitfall of the process is the slow growth of the anammox bacteria and the slow startup of anammox process in new reactors.

Another application of the anammox process is in treating recirculating water systems with the potential of providing significant oxygen and energy savings (van Rijn et al. 2006). The presence of organisms related to anammox has been demonstrated in biofilters from marine and freshwater recirculating aquaculture systems (Tal et al. 2003).

Members of Crenarchaeota that can perform ammonia oxidation have been also found in several man-made environments. Normally, nitrifying bacteria are largely responsible for the oxidation of ammonia in aquaria biofilters and recirculation aquaculture (Burrell et al. 2001). However, recently, it has been demonstrated that the nitrifying community in a marine aquarium biofilter was dominated by $\mathrm{AOA}$ instead of $\mathrm{AOB}$, with a ratio of archaeal amoA to bacterial amoA ranging from 1.8 to 3.0 (Urakawa et al. 2008). Furthermore, it was demonstrated that temperature was the most important factor controlling the growth and diversity of $\mathrm{AOA}$ and $\mathrm{AOB}$ in aquaria biofilters. The role of AOA in this kind of system is still unknown.

AOA have also been detected in groundwater treatment plants and associated distribution systems (de Vet et al. 2009; van der Wielen et al. 2009). In one study, it was demonstrated that AOA were responsible for the removal of nitrogen in at least one of the plants studied, suggesting that high DOC levels might reduce growth of AOA (van der Wielen et al. 2009).

More detailed studies concerning to the role of AOA in nitrogen removal from engineered systems have been conducted in wastewater treatment bioreactors (Park et al. 2006; Zhang et al. 2009). AOA appear to be spread in WWTPs: Their dependence upon oxygen concentration and solid retention time was demonstrated in a study examining five plants through the US (Park et al. 2006). It was recently demonstrated using $\mathrm{qPCR}$ analyses of the amoA gene that the $\mathrm{AOB}$ community was more than three orders of magnitude more abundant than the AOA community in an activated sludge bioreactor (Wells et al. 2009). This study suggests that AOA have only a minor role in ammonia oxidation in highly aerated activated sludge.

\section{Outlook}

Molecular approaches have contributed significantly to our present knowledge on ecology, distribution, and phylogeny of ammonia-oxidizing microorganisms and on the contribution of AOB, AOA, and anammox to ammonia oxidation. These methods also made possible the study of a largely diverse array of habitats, such as soils, fresh waters, marine habitats, 
and extreme habitats, in particular regarding temperature and salinity. Nevertheless, we expect many challenges to be waiting ahead. In an attempt to understand the ecosystem function, the relative contributions of different AOM to ammonia oxidation and the quantitative determination of their metabolic rates need to be studied and compared in different environments and ecological niches. Some studies with focus on the relative importance of aerobic ammonia oxidizers suggest the numerical dominance of AOA over AOB (Leininger et al. 2006; Mincer et al. 2007; Wuchter et al. 2006). However, recent evidence supports the view that numerical dominance is not necessarily a reliable indicator of activity (Jia and Conrad 2009). Similarly, aerobic and anaerobic ammonia oxidizers are expected to inhabit different ecological niches governed by the availability of oxygen, yet there is evidence that in nature the two groups cooperate (Lam et al. 2007, 2009). In addition, the analysis of the available genome sequences from AOM has highlighted their metabolic complexity and suggests the possibility of different functions of individual AOM under different environmental conditions. These data also suggest a multiple evolutionary origin of ammonia oxidation and imply that a universal molecular marker to study ammonia oxidation in the environment does not exist. Multiple complementary approaches are probably our best bet to unveil the natural diversity of $\mathrm{AOM}$ and their ecological function.

Acknowledgments We would like to thank two anonymous reviewers for their comments and suggestions to improve this work. We apologize to those authors whose work escape our attention or that could not be included here due to space constrains.

Open Access This article is distributed under the terms of the Creative Commons Attribution Noncommercial License which permits any noncommercial use, distribution, and reproduction in any medium, provided the original author(s) and source are credited.

\section{References}

Aakra A, Utaker JB, Nes IF (1999) RFLP of rRNA genes and sequencing of the $16 \mathrm{~S}-23 \mathrm{~S}$ rDNA intergenic spacer region of ammonia-oxidizing bacteria: a phylogenetic approach. Int J Syst Bacteriol 49:123-130

Ahn YH, Hwang IS, Min KS (2004) ANAMMOX and partial denitritation in anaerobic nitrogen removal from piggery waste. Water Sci Technol 49:145-153

Arp DJ, Yeager CM, Hyman MR (2001) Molecular and cellular fundamentals of aerobic cometabolism of trichloroethylene. Biodegradation 12:81-103

Arp DJ, Sayavedra-Soto LA, Hommes NG (2002) Molecular biology and biochemistry of ammonia oxidation by Nitrosomonas europaea. Arch Microbiol 178:250-255

Arp DJ, Chain PS, Klotz MG (2007) The impact of genome analyses on our understanding of ammonia-oxidizing bacteria. Annu Rev Microbiol 61:503-528
Auguet J-C, Casamayor EO (2008) A hotspot for cold crenarchaeota in the neuston of high mountain lakes. Environ Microbiol 10:1080-1086

Auguet JC, Borrego CM, Baneras L, Casamayor EO (2008) Fingerprinting the genetic diversity of the biotin carboxylase gene $(a c c C)$ in aquatic ecosystems as a potential marker for studies of carbon dioxide assimilation in the dark. Environ Microbiol 10:2527-2536

Avrahami S, Conrad R, Braker G (2002) Effect of soil ammonium concentration on $\mathrm{N} 2 \mathrm{O}$ release and on the community structure of ammonia oxidizers and denitrifiers. Appl Environ Microbiol 68:5685-5692

Bano N, Hollibaugh JT (2000) Diversity and distribution of DNA sequences with affinity to ammonia-oxidizing bacteria of the $\beta$ subdivision of the class Proteobacteria in the Arctic Ocean. Appl Environ Microbiol 66:1960-1969

Beman JM, Popp BN, Francis CA (2008) Molecular and biogeochemical evidence for ammonia oxidation by marine Crenarchaeota in the Gulf of California. ISME J 2:429-441

Bergmann DJ, Hooper AB, Klotz MG (2005) Structure and sequence conservation of hao cluster genes of autotrophic ammoniaoxidizing bacteria: evidence for their evolutionary history. Appl Environ Microbiol 71:5371-5382

Bothe H, Jost G, Schloter M, Ward BB, Witzel K-P (2000) Molecular analysis of ammonia oxidation and denitrification in natural environments. FEMS Microbiol Rev 24:673-690

Broda E (1977) Two kinds of lithotrophs missing in nature. Z Allg Mikrobiol 17:491-493

Burrell PC, Phalen CM, Hovanec TA (2001) Identification of bacteria responsible for ammonia oxidation in freshwater aquaria. Appl Environ Microbiol 67:5791-5800

Burton SAQ, Prosser JI (2001) Autotrophic ammonia oxidation at low $\mathrm{pH}$ through urea hydrolysis. Appl Environ Microbiol 67:2952-2957

Byrne N, Strous M, Crépeau V et al (2009) Presence and activity of anaerobic ammonium-oxidizing bacteria at deep-sea hydrothermal vents. ISME J 3:117-123

Calvo L, Garcia-Gil LJ (2004) Use of $a m o B$ as a new molecular marker for ammonia-oxidizing bacteria. J Microbiol Methods 57:69-78

Capone DG, Carpenter EJ (1982) Nitrogen fixation in the marine environment. Science 217:1140-1142

Carini SA, Joye SB (2008) Nitrification in Mono Lake, California: activity and community composition during contrasting hydrological regimes. Limnol Oceanogr 53:2546-2557

Casciotti KL, Ward BB (2001) Dissimilatory nitrite reductase genes from autotrophic ammonia-oxidizing bacteria. Appl Environ Microbiol 67:2213-2221

Casciotti KL, Ward BB (2005) Phylogenetic analysis of nitric oxide reductase gene homologues from aerobic ammonia-oxidizing bacteria. FEMS Microbiol Ecol 52:197-205

Chain P, Lamerdin J, Larimer F et al (2003) Complete genome sequence of the ammonia-oxidizing bacterium and obligate chemolithoautotroph Nitrosomonas europaea. J Bacteriol $185: 2759-2773$

Conrad R (1996) Soil microorganisms as controllers of atmospheric trace gases $\left(\mathrm{H}_{2}, \mathrm{CO}, \mathrm{CH}_{4}, \mathrm{OCS}, \mathrm{N}_{2} \mathrm{O}\right.$, and NO). Microbiol Rev 60:609-640

Dalsgaard T, Canfield DE, Petersen J, Thamdrup B, Acuna-Gonzalez J (2003) N2 production by the anammox reaction in the anoxic water column of Golfo Dulce, Costa Rica. Nature 422:606-608

de la Torre JR, Walker CB, Ingalls AE, Könneke M, Stahl DA (2008) Cultivation of a thermophilic ammonia oxidizing archaeon synthesizing crenarchaeol. Environ Microbiol 10:810-818

de Vet WWJM, Dinklab IJT, Muyzer G, Rietveld LC, van Loosdrecht MCM (2009) Molecular characterization of microbial populations in groundwater sources and sand filters for drinking water production. Water Res 43:182-194 
DeLong EF (1992) Archaea in coastal marine environments. Proc Natl Acad Sci USA 89:5685-5689

DeLong EF (1998) Everything in moderation: archaea as "nonextremophiles". Curr Opin Gen Dev 8:649-654

Dionisi HM, Layton AC, Harms G, Gregory IR, Robinson KG, Sayler GS (2002a) Quantification of Nitrosomonas oligotropha-like ammonia-oxidizing bacteria and Nitrospira spp. from full-scale wastewater treatment plants by competitive PCR. Appl Environ Microbiol 68:245-253

Dionisi HM, Layton AC, Robinson KG, Brown JR, Gregory IR, Parker JJ, Sayler GS (2002b) Quantification of Nitrosomonas oligotropha and Nitrospira spp. using competitive polymerase chain reaction in bench-scale wastewater treatment reactors operating at different solids retention times. Water Environ Res $74: 462-469$

Dorador C (2007) Microbial diversity in high altitude wetlands of the Chilean altiplano: phylogeny, diversity and function. Thesis, University of Kiel, Kiel

Dorador C, Busekow A, Vila I, Imhoff JF, Witzel K-P (2008) Molecular analysis of enrichment cultures of ammonia oxidizers from the Salar de Huasco, a high altitude saline wetland in northern Chile. Extremophiles 12:405-414

Edgar RC (2004) MUSCLE: multiple sequence alignment with high accuracy and high throughput. Nucleic Acids Res 32:1792-1797

El Sheikh AF, Poret-Peterson AT, Klotz MG (2008) Characterization of two new genes, amoR and $a m o D$, in the amo operon of the marine ammonia oxidizer Nitrosococcus oceani ATCC 19707. Appl Environ Microbiol 74:312-318

Erguder TH, Boon N, Wittebolle L, Marzorati M, Verstraete W (2009) Environmental factors shaping the ecological niches of ammoniaoxidizing archaea. FEMS Microbiol Rev 33:855-869

Francis CA, Roberts KJ, Beman JM, Santoro AE, Oakley BB (2005) Ubiquity and diversity of ammonia-oxidizing archaea in water columns and sediments of the ocean. Proc Natl Acad Sci USA 102:14683-14688

Freitag TE, Prosser JI (2004) Differences between betaproteobacterial ammonia-oxidizing communities in marine sediments and those in overlying water. Appl Environ Microbiol 70:3789-3793

Fuhrman JA, McCallum K, Davis AA (1992) Novel major archaebacterial group from marine plankton. Nature 356:148-149

Galan A, Ulloa O, Molina V, Thamdrup B, Woebken D, Lavik D, Kuypers MM (2009) Anammox bacteria and the anaerobic oxidation of ammonium in the oxygen minimum zone off northern Chile. Deep Sea Res Part II Top Stud Oceanogr 56:1021-1031. doi:10.1016/j.dsr1012.2008.1009.1016

Gieseke A, Purkhold U, Wagner M, Amann R, Schramm A (2001) Community structure and activity dynamics of nitrifying bacteria in a phosphate-removing biofilm. Appl Environ Microbiol 67:1351-1362

Gieseke A, Tarre S, Green M, de Beer D (2006) Nitrification in a biofilm at low $\mathrm{pH}$ values: role of in situ microenvironments and acid tolerance. Appl Environ Microbiol 72:4283-4292

Guindon S, Gascuel O (2003) A simple, fast, and accurate algorithm to estimate large phylogenies by maximum likelihood. Syst Biol 52:696-704

Hallam SJ, Mincer TJ, Schleper C, Preston CM, Roberts K, Richardson PM, DeLong EF (2006a) Pathways of carbon assimilation and ammonia oxidation suggested by environmental genomic analyses of marine Crenarchaeota. PLoS Biol 4:e95

Hallam SJ, Konstantinidis KT, Putnam N et al (2006b) Genomic analysis of the uncultivated marine crenarchaeote Cenarchaeum symbiosum. Proc Natl Acad Sci USA 103:18296-18301

Hallin S, Lydmark P, Kokalj S, Hermansson M, Sorensson F, Jarvis A, Lindgren PE (2005) Community survey of ammonia-oxidizing bacteria in full-scale activated sludge processes with different solids retention time. J Appl Microbiol 99:629-640
Hastings RC, Ceccherini MT, Miclaus N, Saunders JR, Bazzicalupo M, McCarthy AJ (1997) Direct molecular biological analysis of ammonia oxidizing bacteria populations in cultivated soil plots treated with swine manure. FEMS Microbiol Ecol 23:45-54

Hatzenpichler R, Lebedeva EV, Spieck E, Stoecker K, Richter A, Daims H, Wagner M (2008) A moderately thermophilic ammonia-oxidizing crenarchaeote from a hot spring. Proc Natl Acad Sci USA 105:2134-2139

Head IM, Hiorns WD, Embley TM, McCarthy AJ, Saunders JR (1993) The phylogeny of autotrophic ammonia-oxidizing bacteria as determined by analysis of $16 \mathrm{~S}$ ribosomal RNA gene sequences. J Gen Microbiol 139:1147-1153

Hellinga C, Schellen AAJC, Mulder JW, van Loosdrecht MCM, Heijnen JJ (1998) The SHARON process: an inovative method for nitrogen removal from ammonium-rich wastewater. Water Sci Technol 37:135-142

Hiorns WD, Hastings RC, Head IM, McCarthy AJ, Saunders JR, Pickup RW, Hall GH (1995) Amplification of 16S ribosomal RNA genes of autotrophic ammonia-oxidizing bacteria demonstrates the ubiquity of nitrosospiras in the environment. Microbiology 141:2793-2800

Hirayama H, Takai K, Inagaki F, Yamato Y, Suzuki M, Nealson KH, Horikoshi K (2005) Bacterial community shift along a subsurface geothermal water stream in a Japanese gold mine. Extremophiles 9:169-184

Hollibaugh JT, Bano N, Ducklow HW (2002) Widespread distribution in polar oceans of a $16 \mathrm{~S}$ rRNA gene sequence with affinity to Nitrosospira-like ammonia-oxidizing bacteria. Appl Environ Microbiol 68:1478-1484

Holmes AJ, Costello A, Lidstrom ME, Murrell JC (1995) Evidence that particulate methane monooxygenase and ammonia monooxygenase may be evolutionary related. FEMS Microbiol Lett 132:203-208

Hooper A, Arciero D, Bergmann D, Hendrich MP (2005) The oxidation of ammonia as an energy source in bacteria in respiration. In: Zannoni D (ed) Respiration in archaea bacteria. Springer, Dordrecht, pp 121-147

Hoshino T, Noda N, Tsuneda S, Hirata A, Inamori Y (2001) Direct detection by in situ PCR of the amoA gene in biofilm resulting from a nitrogen removal process. Appl Environ Microbiol 67:5261-5266

Igarashi N, Moriyama H, Fujiwara T, Fukumori Y, Tanaka N (1997) The 2.8 A structure of hydroxylamine oxidoreductase from a nitrifying chemoautotrophic bacterium, Nitrosomonas europaea. Nat Struct Biol 4:276-284

Jetten MS, Wagner M, Fuerst J, van Loosdrecht M, Kuenen G, Strous M (2001) Microbiology and application of the anaerobic ammonium oxidation ('anammox') process. Curr Opin Biotechnol 12:283-288

Jetten MS, Cirpus I, Kartal B et al (2005) 1994-2004: 10 years of research on the anaerobic oxidation of ammonium. Biochem Soc Trans 33:119-123

Jia Z, Conrad R (2009) Bacteria rather than Archaea dominate microbial ammonia oxidation in an agricultural soil. Environ Microbiol 11:1658-1671

Jiang H, Dong H, Yu B, Lv G, Deng S, Berzins N, Dai M (2009) Diversity and abundance of ammonia-oxidizing archaea and bacteria in Qinghai Lake, northwestern China. Geomicrobiology J 26:199-211

Jones RD, Morita RY (1985) Low-temperature growth and whole-cell kinetics of a marine ammonium oxidizer. Mar Ecol Prog Ser 21:239-243

Jones RD, Morita RY, Koops H-P, Watson SW (1988) A new marine ammonium-oxidizing bacterium, Nitrosomonas cryotolerans $\mathrm{sp}$. nov. Can J Microbiol 34:1122-1128 
Junier P, Kim OS, Hadas O, Imhoff JF, Witzel KP (2008a) Evaluation of PCR primer selectivity and phylogenetic specificity by using amplification of $16 \mathrm{~S}$ rRNA genes from betaproteobacterial ammonia-oxidizing bacteria in environmental samples. Appl Environ Microbiol 74:5231-5236

Junier P, Kim OS, Molina V, Limburg P, Junier T, Imhoff JF, Witzel KP (2008b) Comparative in silico analysis of PCR primers suited for diagnostics and cloning of ammonia monooxygenase genes from ammonia-oxidizing bacteria. FEMS Microbiol Ecol 64:141-152

Junier P, Kim OS, Junier T, Ahn TS, Imhoff JF, Witzel KP (2009) Community analysis of betaproteobacterial ammonia-oxidizing bacteria using the amoCAB operon. Appl Microbiol Biotechnol $83: 175-188$

Juretschko S, Timmermann G, Schmid M, Schleifer KH, Pommerening-Röser A, Koops HP, Wagner M (1998) Combined molecular and conventional analyses of nitrifying bacterium diversity in activated sludge: Nitrosococcus mobilis and Nitrospira-like bacteria as dominant populations. Appl Environ Microbiol 64:3042-3051

Karner MB, DeLong EF, Karl DM (2001) Archaeal dominance in the mesopelagic zone of the Pacific Ocean. Nature 409:507-510

Kartal B, Koleva M, Arsov R, van der Star W, Jetten MS, Strous M (2006) Adaptation of a freshwater anammox population to high salinity wastewater. J Biotechnol 126:546-553

Kartal B, Kuypers MM, Lavik G, Schalk J, Op den Camp HJ, Jetten MS, Strous M (2007) Anammox bacteria disguised as denitrifiers: nitrate reduction to dinitrogen gas via nitrite and ammonium. Environ Microbiol 9:635-642

Khin T, Annachhatre AP (2004) Novel microbial nitrogen removal processes. Biotechnol Adv 22:519-532

Kim O-S, Junier P, Imhoff JF, Witzel K-P (2006) Comparative analysis of ammonia-oxidizing bacterial communities in two lakes in North Germany and the Baltic Sea. Arch Hydrobiol 167:335-350

Kim OS, Junier P, Imhoff JF, Witzel KP (2008) Comparative analysis of ammonia monooxygenase (amoA) genes in the water column and sediment-water interface of two lakes and the Baltic Sea. FEMS Microbiol Ecol 66:367-378

Klotz MG, Arp DJ, Chain PS et al (2006) Complete genome sequence of the marine, chemolithoautotrophic, ammonia-oxidizing bacterium Nitrosococcus oceani ATCC 19707. Appl Environ Microbiol 72:6299-6315

Klotz MG, Schmid MC, Strous M, op den Cam HJ, Jetten MS, Hooper AB (2008) Evolution of an octahaem cytochrome c protein family that is key to aerobic and anaerobic ammonia oxidation by bacteria. Environ Microbiol 10:3150-3163

Könneke M, Bernhard AE, de la Torre JR, Walker CB, Waterbury JB, Stahl DA (2005) Isolation of an autotrophic ammonia-oxidizing marine archaeon. Nature 437:543-546

Koop-Jakobsen K, Giblin AE (2009) Anammox in tidal marsh sediments: the role of salinity, nitrogen loading, and marsh vegetation. Estuar Coast 32:238-245

Koops HP, Purkhold U, Pommerening-Röser A, Timmermann G, Wagner M (2003) The lithoautotrophic ammonia-oxidizing bacteria. In: Dworkin M (ed) The prokaryotes. Springer, New York

Kowalchuk GA, Stephen JR (2001) Ammonia-oxidizing bacteria: a model for molecular microbial ecology. Annu Rev Microbiol 55:485-529

Kowalchuk GA, Stephen JR, De Boer W, Prosser JI, Embley TM, Woldendorp JW (1997) Analysis of ammonia-oxidizing bacteria of the beta subdivision of the class Proteobacteria in coastal sand dunes by denaturing gradient gel electrophoresis and sequencing of PCR-amplified 16S ribosomal DNA fragments. Appl Environ Microbiol 63:1489-1497
Kuypers MM, Sliekers AO, Lavik G et al (2003) Anaerobic ammonium oxidation by anammox bacteria in the Black Sea. Nature 422:608-611

Kuypers MM, Lavik G, Woebken D et al (2005) Massive nitrogen loss from the Benguela upwelling system through anaerobic ammonium oxidation. Proc Natl Acad Sci USA 102:6478-6483

Lam P, Jensen MM, Lavik G et al (2007) Linking crenarchaeal and bacterial nitrification to anammox in the Black Sea. Proc Natl Acad Sci USA 104:7104-7109

Lam P, Lavik G, Jensen MM et al (2009) Revising the nitrogen cycle in the Peruvian oxygen minimum zone. Proc Natl Acad Sci USA 106:4752-4757

Layton AC, Dionisi H, Kuo HW, Robinson KG, Garrett VM, Meyers A, Sayler GS (2005) Emergence of competitive dominant ammonia-oxidizing bacterial populations in a full-scale industrial wastewater treatment plant. Appl Environ Microbiol 71:11051108

Lebedeva EV, Alawi M, Fiencke C, Namsaraev B, Bock E, Spieck E (2005) Moderately thermophilic nitrifying bacteria from a hot spring of the Baikal rift zone. FEMS Microbiol Ecol 54:297-306

Leininger S, Urich T, Schloter M et al (2006) Archaea predominate among ammonia-oxidizing prokaryotes in soils. Nature 442:806809

McCaig AE, Embley TM, Prosser JI (1994) Molecular analysis of enrichment cultures of marine ammonia oxidisers. FEMS Microbiol Lett 120:363-367

McTavish H, Fuchs JA, Hooper AB (1993) Sequence of the gene coding for ammonia monooxygenase in Nitrosomonas europaea. J Bacteriol 175:2436-2444

Mincer TJ, Church MJ, Taylor LT, Preston C, Karl DM, DeLong EF (2007) Quantitative distribution of presumptive archaeal and bacterial nitrifiers in Monterey Bay and the North Pacific Subtropical Gyre. Environ Microbiol 9:1162-1175

Mobarry BK, Wagner M, Urbain V, Rittmann BE, Stahl DA (1996) Phylogenetic probes for analyzing abundance and spatial organization of nitrifying bacteria. Appl Environ Microbiol 62:2156-2162

Molina V, Ulloa O, Farías L, Urrutia H, Ramírez S, Junier P, Witzel K-P (2007) Ammonia-oxidizing $\beta$-proteobacteria from the oxygen minimum zone off northern Chile. Appl Environ Microbiol 73:3547-3555

Moran MA, Buchan A, Gonzalez JM et al (2004) Genome sequence of Silicibacter pomeroyi reveals adaptations to the marine environment. Nature 432:910-913

Mulder A, van de Graaf AA, Robertson LA, Kuenen JG (1995) Anaerobic ammonium oxidation discovered in a denitrifying fluidized bed reactor. FEMS Microbiol Ecol 16:177-184

Mulder JW, van Loosdrecht MC, Hellinga C, van Kempen R (2001) Full-scale application of the SHARON process for treatment of rejection water of digested sludge dewatering. Water Sci Technol 43:127-134

Nicol GW, Schleper C (2006) Ammonia-oxidising Crenarchaeota: important players in the nitrogen cycle? Trends Microbiol 14:207-212

Nicol GW, Leininger S, Schleper C, Prosser JI (2008) The influence of soil $\mathrm{pH}$ on the diversity, abundance and transcriptional activity of ammonia oxidizing archaea and bacteria. Environ Microbiol 10:2966-2978

Nicolaisen MH, Ramsing NB (2002) Denaturing gradient gel electrophoresis (DGGE) approaches to study the diversity of ammonia-oxidizing bacteria. J Microbiol Methods 50:189203

Nold SC, Zhou J, Devol AH, Tiedje JM (2000) Pacific Northwest marine sediments contain ammonia-oxidizing bacteria in the beta subdivision of the proteobacteria. Appl Environ Microbiol $66: 4532-4535$ 
Norton JM, Alzerreca JJ, Suwa Y, Klotz MG (2002) Diversity of ammonia monooxygenase operon in autotrophic ammoniaoxidizing bacteria. Arch Microbiol 177:139-149

Norton JM, Klotz MG, Stein LY et al (2008) Complete genome sequence of Nitrosospira multiformis, an ammonia-oxidizing bacterium from the soil environment. Appl Environ Microbiol 74:3559-3572

Nugroho RA, Rolling WFM, Laverman AM, Verhoef HA (2007) Low nitrification rates in acid Scots pine forest soils are due to $\mathrm{pH}-$ related factors. Microb Ecol 53:87-97

Ochsenreiter T, Selezi D, Quaiser A, Bonch-Osmolovskaya L, Schleper C (2003) Diversity and abundance of Crenarchaeota in terrestrial habitats studied by $16 \mathrm{~S}$ RNA surveys and real time PCR. Environ Microbiol 5:787-797

Okano Y, Hristova KR, Leutenegger CM et al (2004) Application of real-time PCR to study effects of ammonium on population size of ammonia-oxidizing bacteria in soil. Appl Environ Microbiol 70:1008-1016

O'Mullan GD, Ward BB (2005) Relationship of temporal and spatial variabilities of ammonia-oxidizing bacteria to nitrification rates in Monterey Bay, California. Appl Environ Microbiol 71:697705

Op den Camp HJ, Kartal B, Guven D et al (2006) Global impact and application of the anaerobic ammonium-oxidizing (anammox) bacteria. Biochem Soc Trans 34:174-178

Park HD, Wells GF, Bae H, Criddle CS, Francis CA (2006) Occurrence of ammonia-oxidizing archaea in wastewater treatment plant bioreactors. Appl Environ Microbiol 72:5643-5647

Park S-J, Park B-J, Rhee S-K (2008) Comparative analysis of archaeal $16 \mathrm{~S}$ rRNA and amoA genes to estimate the abundance and diversity of ammonia-oxidizing archaea in marine sediments. Extremophiles 12:605-615

Penton CR, Devol AH, Tiedje JM (2006) Molecular evidence for the broad distribution of anaerobic ammonium-oxidizing bacteria in freshwater and marine sediments. Appl Environ Microbiol $72: 6829-6832$

Perreault NN, Andersen DT, Pollard WH, Greer CW, Whyte LG (2007) Characterization of the prokaryotic diversity in cold saline perennial springs of the Canadian high Arctic. Appl Environ Microbiol 73:1532-1543

Phillips CJ, Smith Z, Embley TM, Prosser JI (1999) Phylogenetic differences between particle-associated and planktonic ammoniaoxidizing bacteria of the $\beta$ subdivision of the class Proteobacteria in the northwestern Mediterranean Sea. Appl Environ Microbiol 65:779-786

Pommerening-Roeser A, Rath G, Koops H-P (1996) Phylogenetic diversity within the genus Nitrosomonas. Syst Appl Microbiol 19:344-351

Princic A, Mahne II, Megusar F, Paul EA, Tiedje JM (1998) Effects of $\mathrm{pH}$ and oxygen and ammonium concentrations on the community structure of nitrifying bacteria from wastewater. Appl Environ Microbiol 64:3584-3590

Prosser JI, Embley TM (2002) Cultivation-based and molecular approaches to characterization of terrestrial and aquatic nitrifiers. Antonie Van Leeuwenhoek 81:165-179

Prosser JI, Nicol GW (2008) Relative contributions of archaea and bacteria to aerobic ammonia oxidation in the environment. Environ Microbiol 10:2931-2941

Purkhold U, Pommerening-Röser A, Juretschko S, Schmid MC, Koops HP, Wagner M (2000) Phylogeny of all recognized species of ammonia oxidizers based on comparative 16S rRNA and $a m o A$ sequence analysis: implications for molecular diversity surveys. Appl Environ Microbiol 66:5368-5382

Purkhold U, Wagner M, Timmermann G, Pommerening-Röser A, Koops HP (2003) 16S rRNA and amoA-based phylogeny of 12 novel betaproteobacterial ammonia-oxidizing isolates: extension of the dataset and proposal of a new lineage within the nitrosomonads. Int J Syst Evol Microbiol 53:1485-1494

Reigstad LJ, Richter A, Daims H, Urich T, Schwark L, Schleper C (2008) Nitrification in terrestrial hot springs of Iceland and Kamchatka. FEMS Microbiol Ecol 64:167-174

Rotthauwe J-H, Witzel K-P, Liesack W (1997) The ammonia monooxygenase structural gene amo $A$ as a functional marker: molecular fine-scale analysis of natural ammonia-oxidizing populations. Appl Environ Microbiol 63:4704-4712

Schmid M, Schmitz-Esser S, Jetten M, Wagner M (2001) 16S-23S rDNA intergenic spacer and 23S rDNA of anaerobic ammoniumoxidizing bacteria: implications for phylogeny and in situ detection. Environ Microbiol 3:450-459

Schmid MC, Maas B, Dapena A et al (2005) Biomarkers for in situ detection of anaerobic ammonium-oxidizing (anammox) bacteria. Appl Environ Microbiol 71:1677-1684

Schmid MC, Hooper AB, Klotz MG et al (2008) Environmental detection of octahaem cytochrome c hydroxylamine/hydrazine oxidoreductase genes of aerobic and anaerobic ammoniumoxidizing bacteria. Environ Microbiol 10:3140-3149

Schmidt I, Sliekers O, Schmid M et al (2003) New concepts of microbial treatment processes for the nitrogen removal in wastewater. FEMS Microbiol Rev 27:481-492

Schmidt CS, Hultman KA, Robinson D, Killham K, Prosser JI (2007) PCR profiling of ammonia-oxidizer communities in acidic soils subjected to nitrogen and sulphur deposition. FEMS Microbiol Ecol 61:305-316

Schubert CJ, Durisch-Kaiser E, Wehrli B, Thamdrup B, Lam P, Kuypers MM (2006) Anaerobic ammonium oxidation in a tropical freshwater system (Lake Tanganyika). Environ Microbiol 8:1857-1863

Shimamura M, Nishiyama T, Shigetomo H, Toyomoto T, Kawahara Y, Furukawa K, Fujii T (2007) Isolation of a multiheme protein with features of a hydrazine-oxidizing enzyme from an anaerobic ammonium-oxidizing enrichment culture. Appl Environ Microbiol 73:1065-1072

Sinigalliano CD, Kuhn DN, Jones RD (1995) Amplification of the amo $A$ gene from diverse species of ammonium-oxidizing bacteria and from an indigenous bacterial population from seawater. Appl Environ Microbiol 61:2702-2706

Siripong S, Rittmann BE (2007) Diversity study of nitrifying bacteria in full-scale municipal wastewater treatment plants. Water Res 41:1110-1120

Sliekers AO, Third KA, Abma W, Kuenen JG, Jetten MS (2003) CANON and Anammox in a gas-lift reactor. FEMS Microbiol Lett 218:339-344

Stein LY, Arp DJ, Berube PM et al (2007) Whole-genome analysis of the ammonia-oxidizing bacterium, Nitrosomonas eutropha C91: implications for niche adaptation. Environ Microbiol 9:2993-3007

Stephen J, McCaig A, Smith Z, Prosser J, Embley T (1996) Molecular diversity of soil and marine $16 \mathrm{~S}$ rRNA gene sequences related to beta-subgroup ammonia-oxidizing bacteria. Appl Environ Microbiol 62:4147-4154

Stephen JR, Chang YJ, Macnaughton SJ, Kowalchuk GA, Leung KT, Flemming CA, White DC (1999) Effect of toxic metals on indigenous soil beta-subgroup proteobacterium ammonia oxidizer community structure and protection against toxicity by inoculated metal-resistant bacteria. Appl Environ Microbiol 65:95-101

Strous M, Fuerst JA, Kramer EH et al (1999) Missing lithotroph identified as new planctomycete. Nature 400:446-449

Strous M, Pelletier E, Mangenot S et al (2006) Deciphering the evolution and metabolism of an anammox bacterium from a community genome. Nature 440:790-794

Tal Y, Watts JEM, Schreier SB, Sowers KR, Schreier HJ (2003) Characterization of the microbial community and nitrogen transformation processes associated with moving bed bio-reactors in a closed recirculated mariculture system. Aquaculture 215:187-202 
Tamegai H, Aoki R, Arakawa S, Kato C (2007) Molecular analysis of the nitrogen cycle in deep-sea microorganisms from the Nankai Trough: genes for nitrification and denitrification from deep-sea environmental DNA. Extremophiles 11:269-275

Teske A, Alm E, Regan JM, Toze S, Rittmann BE, Stahl DA (1994) Evolutionary relationships among ammonia- and nitrite-oxidizing bacteria. J Bacteriol 176:6623-6630

Thamdrup B, Dalsgaard T (2002) Production of $\mathrm{N}(2)$ through anaerobic ammonium oxidation coupled to nitrate reduction in marine sediments. Appl Environ Microbiol 68:1312-1318

Third KA, Sliekers AO, Kuenen JG, Jetten MS (2001) The CANON system (completely autotrophic nitrogen-removal over nitrite) under ammonium limitation: interaction and competition between three groups of bacteria. Syst Appl Microbiol 24:588-596

Third KA, Paxman J, Schmid M, Strous M, Jetten MS, Cord-Ruwisch R (2005) Treatment of nitrogen-rich wastewater using partial nitrification and anammox in the CANON process. Water Sci Technol 52:47-54

Tourna M, Freitag TE, Nicol GW, Prosser JI (2008) Growth, activity and temperature responses of ammonia-oxidizing archaea and bacteria in soil microcosms. Environ Microbiol 10:1357-1364

Treusch AH, Leininger S, Kletzin A, Schuster SC, Klenk HP, Schleper C (2005) Novel genes for nitrite reductase and Amo-related proteins indicate a role of uncultivated mesophilic crenarchaeota in nitrogen cycling. Environ Microbiol 7:1985-1995

Urakawa H, Tajima Y, Numata Y, Tsuneda S (2008) Low temperature decreases the phylogenetic diversity of ammonia-oxidizing archaea and bacteria in aquarium biofiltration systems. Appl Environ Microbiol 74:894-900

Utaker JB, Nes IF (1998) A qualitative evaluation of the published oligonucleotides specific for the 16S rRNA gene sequences of the ammonia-oxidizing bacteria. Syst Appl Microbiol 21:72-88

van de Graaf AA, Mulder A, de Bruijn P, Jetten MS, Robertson LA, Kuenen JG (1995) Anaerobic oxidation of ammonium is a biologically mediated process. Appl Environ Microbiol 61:12461251

van der Star WR, Abma WR, Blommers D et al (2007) Startup of reactors for anoxic ammonium oxidation: experiences from the first full-scale anammox reactor in Rotterdam. Water Res 41:4149-4163

van der Wielen PW, Voost S, van der Kooij D (2009) Ammoniaoxidizing bacteria and archaea in groundwater treatment and drinking water distribution systems. Appl Environ Microbiol 75:4687-4695

van Dongen U, Jetten MS, van Loosdrecht MC (2001) The SHARON-Anammox process for treatment of ammonium rich wastewater. Water Sci Technol 44:153-160

van Rijn J, Tal Y, Schreier HJ (2006) Denitrification in recirculating systems: theory and applications. Aquac Eng 34:364-376
Venter JC, Remington K, Heidelberg JF et al (2004) Environmental genome shotgun sequencing of the Sargasso Sea. Science 304:66-74

Voytek MA, Ward BB (1995) Detection of ammonium-oxidizing bacteria of the beta-subclass of the class Proteobacteria in aquatic samples with the PCR. Appl Environ Microbiol 61:1444-1450

Wagner M, Loy A (2002) Bacterial community composition and function in sewage treatment systems. Curr Opin Biotechnol 13:218-227

Wagner M, Rath G, Amman R, Koops H-P, Schleifer KH (1995) In situ identification of ammonia-oxidizing bacteria. Syst Appl Microbiol 18:251-264

Ward BB, Voytek MA, Witzel KP (1997) Phylogenetic diversity of natural populations of ammonia oxidizers investigated by specific PCR amplification. Microb Ecol 33:87-96

Ward BB, Martino DP, Diaz MC, Joye SB (2000) Analysis of ammonia-oxidizing bacteria from hypersaline Mono Lake, California, on the basis of 16S rRNA sequences. Appl Environ Microbiol 66:2873-2881

Ward N, Larsen O, Sakwa J et al (2004) Genomic insights into methanotrophy: the complete genome sequence of Methylococcus capsulatus (Bath). PLoS Biol 2:e303

Webster G, Embley TM, Prosser JI (2002) Grassland management regimens reduce small-scale heterogeneity and species diversity of beta-proteobacterial ammonia oxidizer populations. Appl Environ Microbiol 68:20-30

Wells GF, Park HD, Yeung CH, Eggleston B, Francis CA, Criddle CS (2009) Ammonia-oxidizing communities in a highly aerated fullscale activated sludge bioreactor: betaproteobacterial dynamics and low relative abundance of Crenarchaea. Environ Microbiol 11:2310-2328

Wickramasinghe S, Borin M, Kotagama SW, Cochard R, Anceno AJ, Shipin OV (2009) Multi-functional pollution mitigation in a rehabilitated mangrove conservation area. Ecol Eng 35:898907

Woebken D, Lam P, Kuypers MM et al (2008) A microdiversity study of anammox bacteria reveals a novel Candidatus Scalindua phylotype in marine oxygen minimum zones. Environ Microbiol 10:3106-3119

Woebken D, Lam P, Kuypers MM et al (2009) A microdiversity study of anammox bacteria reveals a novel Candidatus Scalindua phylotype in marine oxygen minimum zones. Environ Microbiol 10:3106-3119

Wuchter C, Abbas B, Coolen MJ et al (2006) Archaeal nitrification in the ocean. Proc Natl Acad Sci USA 103:12317-12322

Zhang T, Jin T, Yan Q, Shao M, Wells G, Criddle C, PF HH (2009) Occurrence of ammonia-oxidizing archaea in activated sludges of a laboratory scale reactor and two wastewater treatment plants. J Appl Microbiol 107:970-977 